Science prepares students for degree courses to be completed abroad in engineering, physical science, medicine, agticulture, forestry, and veterinary service.

The School of Law gives a four-year academic course through evening classes (six hours a week) to members of the various Ministries and higher officers of the police and the army. Local problems provide a constant approach to all the subjects.

The Extension Department of the Faculty of Arts offers evening courses in the field of Public and Private Administration to employees of the Ministries and private firms.

The Institute of Adult Education offers preparation to the Extension Department and includes courses of Amharic language at different levels for foreigners.

Courses on Africa in general, and on Ethiopia in particular, occupy an important place in the curriculum. Courses on Ethiopian history and archaeology, on Ancient Ethiopic, on the structure of Amharic, and on comparative Ethiopic are required of all seniors and optional for others.

An Ethnography Club dealing with Ethiopian customs and institutions publishes its Bulletin twice a year. An important collection of Ethiopica is at the disposal of the students as well as of outsiders interested in research work.

\title{
Rhodes-Livingstone Institute
}

Communicated by Wolf Leslau

THE seventh conference of research officers of the Institute was held at the Institute's headquarters, Lusaka, Northern Rhodesia, from $\mathrm{I}_{4}$ to 22 October 1953 . The proposal to publish a symposium on labour migration in British Central Africa had been under discussion for some time, and the purpose of the conference was to lay down the main lines of approach to the topic. From the papers read and discussed at the conference it became apparent that it would be more profitable to study the industrial. revolution as a whole, since labour migration was only one aspect of general social change.

The papers read at the conference dealt with various aspects of industrialization and the movement of labour; the changes produced in the migration pattern by the creation of a local labour market and by the development of small farms owned by traders or cash-crop farmers; effects of migration on the age-sex structure of villages and thus on village economy; the shift of authority from older men possessing traditional status to younger men possessing wealth.

The question of methods to be employed in comparative studies was discussed, and the danger of assuming that all Africans now living in towns were necessarily labour migrants normally resident in villages, was emphasized.

\section{Un séminaire de sciences humaines à Astrida}

Du 2 a au 29 décembre se tint au Centre de Recherches Scientifiques du Ruanda-Urundi (I.R.S.A.C.) à Astrida un des séminaires où se réunissent périodiquement les spécialistes en sciences humaines de l'I.R.S.A.C. Y prirent part MM. J. J. Maquet, Chef du Centre, J. Vansina et L. de Heusch, ethnologues; J. Hiernaux, anthropologue physique; A. Coupez et J. Jacobs, linguistes; R. de Wilde et R. Thys, assistants de recherche.

Au cours de la semaine onze communications furent présentées, trois travaux furent élaborés en commun et les programmes de recherches furent établis.

Les questions présentées et discutées dans les diverses communications portèrent sur les sujets suivants: méthodes de recherche en dialectologie (Coupez et Jacobs), croissance et nutrition (Hiernaux), parenté, mariage et valeurs culturelles (de Heusch et Vansina), langue tambourinée (Jacobs), symbolisme de l'initiation (Vansina), sociologie urbaine (Maquet).

Poursuivant un travail qu'ils avaient déjà commencé lors de précédentes réunions, les participants au Séminaire rédigèrent une série de définitions de termes sociologiques et se 
mirent d'accord sur la manière de transcrire les mots africains à employer dans des textes non linguistiques. Enfin ils rédigèrent un questionnaire destiné à faciliter l'application aux langues bantoues de la méthode de $\mathrm{M}$. Swadesh.

Après avoir précisé le programme des travaux qui se poursuivront les prochains mois, chacun rejoignit sa base de recherches sur le terrain.

Communicated by J. J. Maquet, Chef du Centre d'Astrida

\section{Nutrition Studies in the British Dependencies}

The London School of Hygiene and Tropical Medicine provides post-graduate courses for diplomas in public health, tropical medicine and hygiene, and bacteriology.

The Department of Human Nutrition is one of the newest in the School. It was established in I946, and six years later, in co-operation with the Colonial Office, an Applied Nutrition Unit was set up, the main functions of which are the study and exchange of information on colonial nutrition and on the technology of foods of people in the dependencies, and the provision of advice and assistance in field work and investigations. In addition, the Unit gives assistance in the training of personnel from the dependencies in nutrition work.

Since its establishment in 1952 as part of the Department of Nutrition, the Unit has had to deal with a rapidly increasing amount of work. Several of the dependent territories have begun to take an interest in nutrition, particularly in the wider aspects of the subject, such as the estimation of the adequacy of food supplies in relation to the human population, which is now increasing at an unprecedented tate in many areas.

A memorandum on dietary survey technique was distributed, and as a result several territories, including Tanganyika and Uganda, set up territorial nutrition committees to review local problems and to co-ordinate attempts at improvement. Close liaison is being maintained with the Food and Agriculture Organization (F.A.O.) and the World Health Organization (W.H.O.), and with interested individuals at the University Colleges of Nigeria and the West Indies and other institutions.

One problem with which the Unit was asked to assist was the estimation of the quantities of different foods that would be required by the population of the projected new town and port of Tema in the Gold Coast. Another was concerned with the technological and nutritional aspects of food-processing techniques. The increasing urbanization of populations in the dependencies has created a demand for food in a semi-processed state, for example, flour or bread rather than unmilled grain, and the preparation of gari from cassava, the parboiling of rice, the milling of maize and smaller grains, and the preservation of fish are under consideration.

During the year, the Unit assisted many individual workers by evaluating the data collected by them in the field (food-consumption studies, height and weight records, \&c.), and analysed the dietary records obtained by the Survey of Economy in Cocoa-producing Areas in Nigeria.

The Head of the Department of Human Nutrition also directs the work of the Human Nutrition Research Unit of the U.K. Medical Research Council in Gambian villages and at the Field Research Station at Fajara in the Gambia.

Two field studies have been conducted in Gambian villages. One, at Geneiri, was an experiment in the improvement of the health of the villagers by increasing agricultural productivity. This scheme, statted by the Nutrition Field Working Party, was financed from U.K. Colonial Development and Welfare funds for a three-year period from 1947 to I950, and at the end of this time the Gambian Government took over the work. Since that date research has continued and reports have been published on the economics of the village's agriculture, and on the energy expenditure of Africans engaged in various rural 